\title{
Mechanisms of TGF- $\beta$-Induced Differentiation in Human Vascular Smooth Muscle Cells
}

\author{
Yuefeng Tang Xuehui Yang Robert E. Friesel Calvin P.H. Vary Lucy Liaw \\ Center for Molecular Medicine, Maine Medical Center Research Institute, Scarborough, Me., USA
}

\section{Key Words}

Smooth muscle cell $\cdot$ Smad $\cdot$ Transforming growth factor

$\beta \cdot$ ALK receptor $\cdot$ Signaling

\begin{abstract}
Background: Transforming growth factor- $\beta$ (TGF- $\beta$ ) plays an important role in vascular homeostasis through effects on vascular smooth muscle cells (SMC). Fine-tuning of TGF- $\beta$ signaling occurs at the level of ALK receptors or Smads, and is regulated with cell type specificity. Methods: Our goal was to understand TGF- $\beta$ signaling in regulating SMC differentiation marker expression in human SMC. Activation of Smads was characterized, and loss- and gain-of-function reagents used to define ALK pathways. In addition, Smad-independent mechanisms were determined. Results: TGF- $\beta$ type I receptors, ALK1 and ALK5, are expressed in human SMC, and TGF- $\beta 1$ phosphorylates Smad1/5/8 and Smad2/3 in a timeand dosage-dependent pattern. ALK5 activity, not bone morphogenetic protein type I receptors, is required for $\mathrm{Smad}$ phosphorylation. Endoglin, a TGF- $\beta$ type III receptor, is a TGF$\beta 1$ target in SMC, yet endoglin does not modify TGF- $\beta 1$ responsiveness. ALK5, not ALK1, is required for TGF- $\beta 1$-induction of SMC differentiation markers, and ALK5 signals through an ALK5/Smad3- and MAP kinase-dependent pathway. Conclusion: The definition of the specific signaling downstream of TGF- $\beta$ regulating SMC differentiation markers will contribute to a better understanding of vascular disorders involving changes in SMC phenotype.

Copyright $\odot 2011$ S. Karger AG, Basel
\end{abstract}

\section{Introduction}

The transforming growth factor- $\beta$ (TGF- $\beta$ ) superfamily members, including TGF- $\beta$, bone morphogenetic proteins (BMPs), activins, inhibins and mycostatin, play important roles in diverse biological processes such as growth, differentiation and inflammation [1]. TGF- $\beta$ and BMPs are extensively studied in human vascular disease such as hereditary hemorrhagic telangiectasia, atherosclerosis, restenosis and primary pulmonary hypertension [1]. The active TGF- $\beta$ elicits signals through two pairs of receptor transmembrane serine/threonine kinases known as the type II and I receptors, respectively [2]. Following TGF- $\beta$ ligand binding, TGF- $\beta$ type II receptor recruits and phosphorylates the type I receptor, and then propagates the signal by phosphorylating Smad transcription factors. Once activated by TGF- $\beta$ receptors, phosphorylated Smads associate with Smad4 and enter the nucleus, where they associate with other transcriptional repressors and transcriptional activators to modulate target gene expression in a cell type-dependent manner.

TGF- $\beta 1$ regulates phenotype transition in smooth muscle cells (SMC) by regulation of specific contractile proteins such as smooth muscle (SM) $\alpha$-actin, SM22 $\alpha$ and calponin 1 in different cells including 10T1/2 cells, neural crest cells and fibroblasts [3-5]. In human atherosclerotic lesions, the actions of TGF- $\beta$ appear restricted to SM cells in fibrous plaques, but not in fibrofatty lesions, based on Smad expression [6], indicating the possibility

\section{KARGER \\ Fax +4161306 1234 \\ E-Mail karger@karger.ch}

www.karger.com
() 2011 S. Karger AG, Basel

Accessible online at:

www.karger.com/jvr
Dr. Lucy Liaw

Maine Medical Center Research Institute

81 Research Drive

Scarborough, ME 04074 (USA)

Tel. +1 207396 8142,E-Mail liawl@ mmc.org 
of a Smad-independent TGF- $\beta$ signaling pathway human atherosclerotic lesions. Although it is widely held that TGF- $\beta$ can induce SMC contractile gene expression in various cell types including SMC [7-10], the mechanisms are poorly defined. Smad pathways are major signal transduction routes downstream of TGF- $\beta$ receptors, although Smad-independent pathways are also activated [7-9]. Our recent studies highlight TGF- $\beta$ cooperation with other regulators of SMC phenotype, including the Notch pathway. Therefore, our goal was to define the specific TGF- $\beta$ receptor and Smad-mediated pathways involved in TGF- $\beta 1$ signaling in human primary SMC. Secondly, we tested whether endoglin, a TGF- $\beta$ type III receptor that is high expressed in injured arteries and atherosclerotic plaques $[11,12]$, can modify the response to TGF- $\beta 1$ in SMC. This signaling axis was studied with respect to TGF- $\beta$-mediated SMC differentiation. Both Smad-dependent and Smad-independent pathways were examined.

Our results show that TGF- $\beta 1$ can phosphorylate Smad2/3 and Smad1/5/8 in human aortic SM cells (HASMC), and that ALK5, but not BMP type I receptors (ALK1/2/3/6), is required for TGF- $\beta$ to phosphorylate Smad $1 / 5 / 8$, and regulate SMC differentiation. Moreover, the expression of endoglin did not oppose TGF- $\beta 1$-mediated differentiation. We also found that ALK5/Smad3 and MAP kinase signaling are required for TGF- $\beta 1$-induced SMC differentiation. Our findings will aid understanding of the pathways activated by TGF- $\beta$ in human vascular diseases such as atherosclerosis, restenosis, and primary pulmonary hypertension.

\section{Methods}

\section{Cell Culture}

HASMC were purchased from Cambrex, maintained in SmGM2 medium, and used between passages 4 and 7. For experiments involving TGF- $\beta 1$ or BMP stimulation, HASMC were serum starved for $24 \mathrm{~h}$ before addition of growth factors or inhibitors.

\section{Constructs and Gene Expression}

Adenoviral constructs were generated as described [13]. The following constructs are in the pAdlox vector. Human HA-tagged ALK1 construct (K229R), HA-tagged ALK5 (T204D and K232R) and human endoglin were previously characterized. The endoglin construct utilized encodes for the short form of endoglin [14]. Cells were transduced as described $[14,15]$.

\section{Immunoblotting}

Whole-cell extracts were prepared in ice-cold lysis buffer as described [15] and then centrifuged. Immunoblot analyses used anti-calponin (Sigma), anti- $\beta$-actin (Sigma), anti-SM22 $\alpha$ (Abcam), anti-endoglin (BD Bioscience), anti-SM $\alpha$-actin (Sigma), anti-HA (Sigma), anti-pSmad2/3 and anti-pSmad1/5/8 (provided by Volkhard Lindner Maine Medical Center Research Institute, Scarborough, Me. USA), anti-SM22 $\alpha$ (Abcam), anti-Smad1 (Cell Signaling), anti-Smad3 (Cell Signaling) and anti-GFP (Santa Cruz).

\section{Quantitative RT-PCR}

Total RNA was extracted using Tri-reagent (Sigma), treated with RNase-free DNAasel (Promega) and reverse transcribed using 20 pM oligodT with AMV reverse transcriptase (Promega). Quantitative RT-PCR was performed using the iCycler (Bio-Rad) using SYBR green (Bio-Rad) with $20 \mathrm{ng}$ cDNA as template. Each sample was amplified in triplicate. Threshold cycle numbers were calculated at log phase of amplification and normalized to cyclophilin.

Transient Transfection and Luciferase Assay

HASMC were plated at 20,000 cells/well of 24-well plate and transfected $24 \mathrm{~h}$ later using $0.25 \mu \mathrm{g}$ reporter plasmid, $0.75 \mu \mathrm{l} \mathrm{Gene}$ Juice (Invitrogen) and $25 \mathrm{ng}$ renilla luciferase plasmid/well. Cells were serum starved for $24 \mathrm{~h}$ followed by stimulation with TGF- $\beta 1$ for $24 \mathrm{~h}$ and then collected for luciferase assay as described [16]. All experiments were repeated at least three times, and the results from a representative experiment are shown with standard deviations.

Co-Immunoprecipitation Assay

Co-immunoprecipitation was performed as described [17]. For assays with transfected plasmid and adenovirus, $300 \mu \mathrm{g}$ of cell lysate was incubated with $1.5 \mu \mathrm{g}$ antibody overnight at $4^{\circ} \mathrm{C}$ followed by the addition of protein A/G plus agarose beads for one hour at $4^{\circ} \mathrm{C}$. Proteins were eluted and subjected to SDS-PAGE. Western blotting was performed with anti-HA or anti-GFP antibodies.

Statistical Analysis

Statistical analyses were performed using Student's t test with significant difference determined as $\mathrm{p}<0.05$. Data were presented as the means \pm SD.

\section{Results}

TGF- $\beta 1$ Stimulation Phosphorylates Both Smad2/3 and Smad1/5/8 in HASMC

Although it is widely accepted that TGF- $\beta$ induces the phosphorylation of Smad $2 / 3$ through ALK5, TGF- $\beta$ was recently reported to signal via type I receptors, ALK1 and ALK5, to phosphorylate Smad1/5/8 and Smad2/3 in several cell types $[18,19]$. However, no reports have characterized these pathways in primary human SMC. To address this, we first examined the expression of ALK receptors by RT-PCR. We observed that both ALK1 and ALK5 are expressed in primary HASMC 


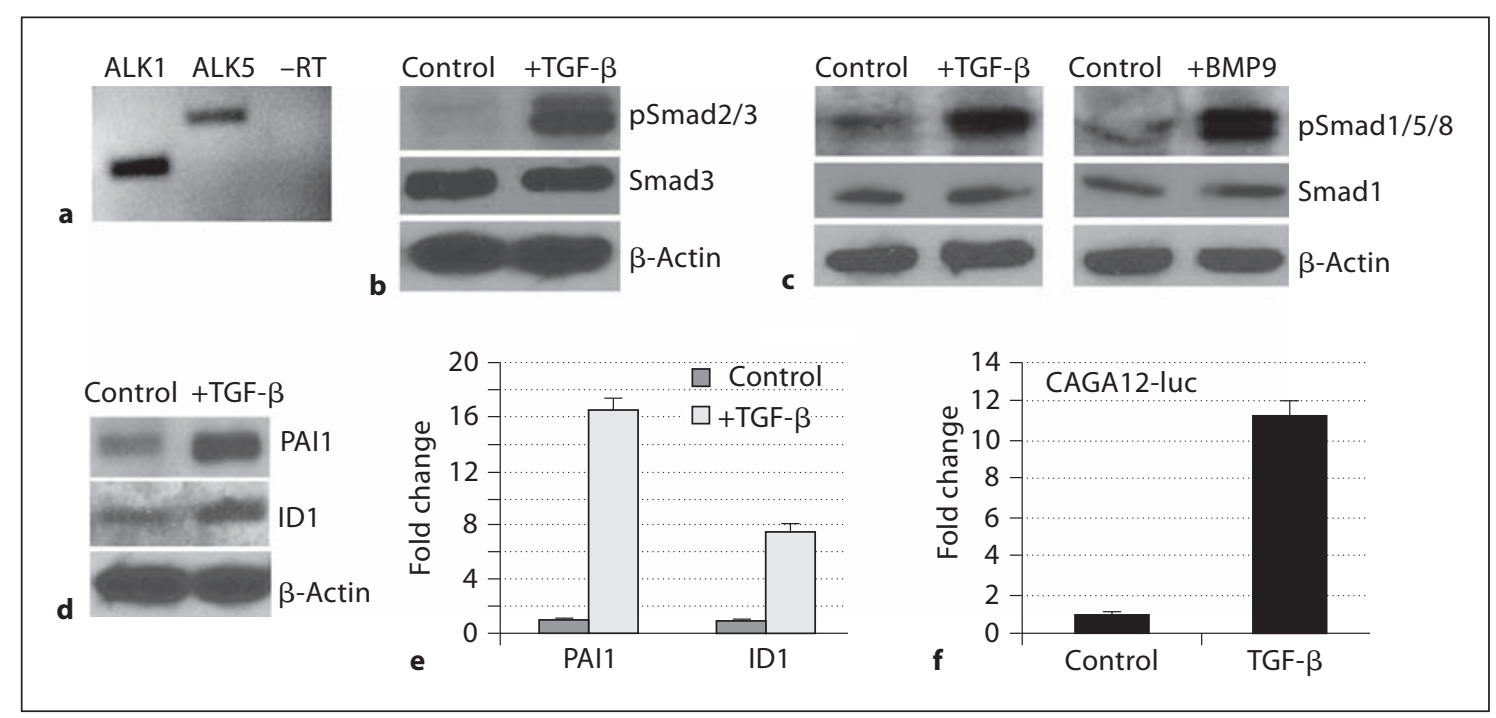

Fig. 1. TGF- $\beta 1$ phosphorylates $S m a d 2 / 3$ and $S m a d 1 / 5 / 8$ in HASMC. a Primary HASMC were collected to detect the expression of ALK1 and ALK5 by RT-PCR. b SMCs were serum starved for $24 \mathrm{~h}$, then treated with $2 \mathrm{ng} / \mathrm{ml}$ TGF- $\beta 1$ for $1 \mathrm{~h}$. Cell lysates were collected after TGF- $\beta$ addition to detect $\mathrm{pSmad} 2 / 3$. Total Smad 3 and $\beta$-actin were used as controls. c SMCs were serum starved for $24 \mathrm{~h}$, then treated with $2 \mathrm{ng} / \mathrm{ml}$ TGF- $\beta 1$ for $1 \mathrm{~h}$. Cell lysates were collected to detect $\mathrm{pSmad} 1 / 5 / 8$ by immunoblot analysis. BMP9-treated samples $(10 \mathrm{ng} / \mathrm{ml}$ for $1 \mathrm{~h}$ ) were used as a positive control for $\mathrm{pSmad} 1 / 5 / 8$. Additionally, total Smad 1 and $\beta$ actin were used as controls. d Serum-starved SMC were treated

(fig. 1a). No PCR products were detected without reverse transcription. We next examined whether TGF- $\beta 1$ can phosphorylate both Smad2/3 and Smad1/5/8 in HASMC. Cells were starved for $24 \mathrm{~h}$ in serum-free medium, and treated with TGF- $\beta 1$ for $1 \mathrm{~h}$ before collection for Western blotting to test for Smad phosphorylation. The immunoblots show that TGF- $\beta 1$ phosphorylates both Smad1/5/8 and Smad2/3 (fig. 1b, c), without changing total levels of Smad 3 or Smad1, suggesting that TGF- $\beta 1$ might activate both type I receptors in HASMC. BMP9treated HASMC were used as a positive control for phosphorylation of Smad1/5/8 (fig. 3c). Immunoblotting with anti- $\beta$-actin was used as a control. To further confirm that TGF- $\beta$ action in HASMC is through $\operatorname{Smad} 2 / 3$ and $S m a d 1 / 5 / 8$, we examined expression of PAI1, an ALK5/Smad2/3 target, and ID1, an ALK1/Smad1/5/8 target. TGF- $\beta 1$ treatment of HASMC induced both PAI1 and ID1 expression at the transcript and protein levels (fig. 1d, e). We also examined the activation of the CAGA12 promoter, which is a reporter specifically activated by the Smad2/3 pathway in response to TGF$\beta$. TGF- $\beta 1$ activates CAGA12 transcriptional activity with $2 \mathrm{ng} / \mathrm{ml}$ TGF- $\beta 1$ for 2 days, and then collected to examine the expression of PAI1 and ID1 by immunoblot. e Serum-starved SMC were treated with $2 \mathrm{ng} / \mathrm{ml} \mathrm{TGF-} \beta 1$ for $24 \mathrm{~h}$ and then total RNA collected for quantitative RT-PCR for PAI1 and ID1. Data are presented as fold change compared to control SMC without TGF- $\beta 1$ treatment \pm standard deviation. $f$ SMC were transduced with CAGA12-luciferase reporter construct and renilla, and then stimulated with $2 \mathrm{ng} / \mathrm{ml}$ TGF- $\beta 1$ for $24 \mathrm{~h}$ after $24 \mathrm{~h}$ of serum starvation. Data are presented as fold change compared to control SMC without TGF- $\beta 1$ stimulation \pm standard deviation.

(fig. 1f), but was unable to activate a reporter construct containing a BMP-responsive element [20], which measures activation of the Smad1/5/8 pathway (data not shown). These data in SMC are consistent with previous work showing that TGF- $\beta 1$ activation of Smad1 phosphorylation does not regulate BMP-responsive elementluciferase activity [19].

\section{TGF- $\beta 1$-Induced Phosphorylation of Smad1/5/8 and \\ Smad2/3 Is Time- and Dosage-Dependent}

The kinetics of TGF- $\beta$-induced Smad phosphorylation is cell type dependent [19]. We studied the kinetics of Smad phosphorylation by TGF- $\beta 1$ in SMCs. The expression of pSmad2/3 was detected after 15 min of stimulation, with a peak level at about $60 \mathrm{~min}$ (fig. 2a). Phosphorylation of $\operatorname{Smad} 2 / 3$ was still observed $3 \mathrm{~h}$ after treatment (fig. 2a), although the signal decreased dramatically. Phosphorylation of Smad1/5/8 was detectable after 15 min, with a peak at $60 \mathrm{~min}$ (fig. 2a). A dose-response curve was performed with increasing TGF- $\beta 1$ concentrations (from 0.2 to $5 \mathrm{ng} / \mathrm{ml}$ ). Cells were stimulated for $1 \mathrm{~h}$ before collection. Phosphorylation of $\operatorname{Smad} 2 / 3$ and $S \operatorname{mad} 1 / 5 / 8$ by 


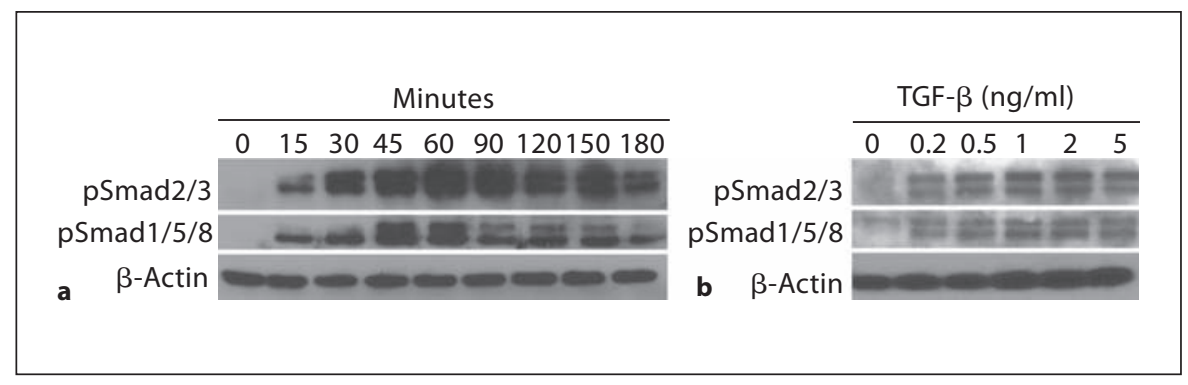

Fig. 2. The kinetics of TGF- $\beta 1$-induced Smad phosphorylation. a Primary HASMC were serum starved for $24 \mathrm{~h}$, and then stimulated with $2 \mathrm{ng} / \mathrm{ml}$ TGF- $\beta 1$ for various times before collection to examine $\mathrm{pSmad} 2 / 3$ and $\mathrm{pSmad} 1 / 5 / 8$. b SMC were serum starved for $24 \mathrm{~h}$, and then treated with increasing TGF- $\beta 1$ concentrations for $1 \mathrm{~h}$. Cell lysates were collected after TGF- $\beta$ addition to test $\mathrm{pSmad} 2 / 3$ and $\mathrm{pSmad} 1 / 5 / 8$ by immunoblot analysis.

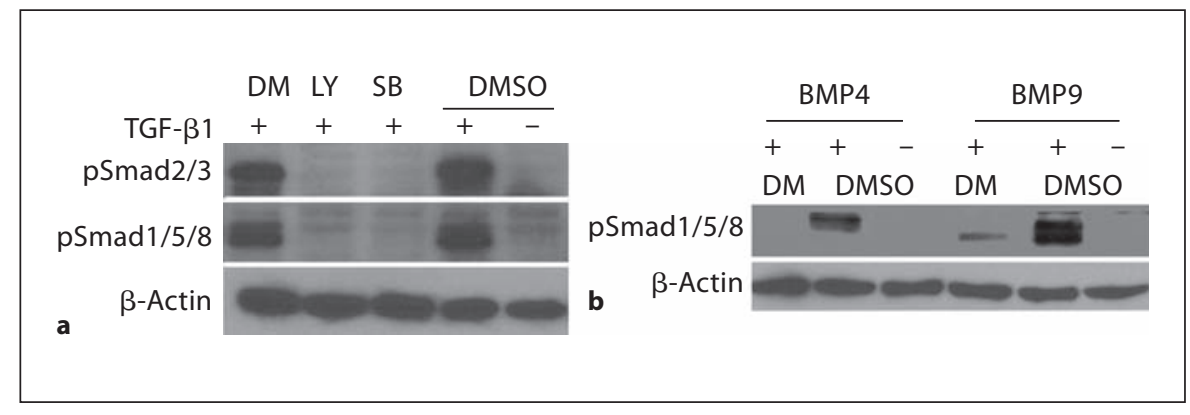

Fig. 3. TGF- $\beta 1$-induced Smad1/5/8 phosphorylation is BMP-independent. a Primary HASMC were serum starved for $24 \mathrm{~h}$, and pretreated with $10 \mu \mathrm{M}$ SB431542 (SB), $10 \mu \mathrm{M}$ LY364947 (LY), 10 $\mu \mathrm{M}$ dorsomorphin (DM) or DMSO for $3 \mathrm{~h}$, and then used as control (-) or stimulated with $2 \mathrm{ng} / \mathrm{ml} \mathrm{TGF}-\beta 1$ for $1 \mathrm{~h}(+)$. Cell lysates were collected to examine $\mathrm{pSmad} 2 / 3$ and $\mathrm{pSmad} 1 / 5 / 8$. b SMC were serum starved for $24 \mathrm{~h}$, and pretreated with $10 \mu \mathrm{M} \mathrm{DM}$ or DMSO (D) for $3 \mathrm{~h}$, and then used as control (-) or treated with (+) BMP4 or BMP9 for $1 \mathrm{~h}$. Cell lysates were collected after BMP treatment to test $\mathrm{pSmad} 2 / 3$ and $\mathrm{pSmad} 1 / 5 / 8$ by immunoblot analysis.
TGF- $\beta 1$ is dosage dependent at low concentrations (less than $1 \mathrm{ng} / \mathrm{ml}$; fig. $2 \mathrm{~b}$ ), and both had similar dose responsiveness to TGF- $\beta 1$.

\section{TGF- $\beta 1$-Induced Smad1/5/8 Phosphorylation Is}

Independent of BMP Type I Receptors in SMC

In endothelial cells, TGF- $\beta$-induced Smad1/5/8 phosphorylation is ALK1 dependent [21]. In HaCaT cells, ALK2 is required for TGF- $\beta$ phosphorylation of Smad1/5/8 [22]. Recent studies indicate that TGF- $\beta$ does not need BMP type I receptors for Smad1/5/8 phosphorylation in some cell types [19]. To determine the requirement for BMP type I receptors in TGF- $\beta 1$-induced Smad1/5/8 phosphorylation in SMC, we utilized the established and specific ALK inhibitors SB431542 [23] (inhibitor of ALK4/5/7) and dorsomorphin (DM, inhibitor of ALK2/3/6) [24]. DM has also been reported to inhibit
ALK1 activity [19]. HASMC were pretreated with ALK inhibitor SB431542, LY364947 or DM for $3 \mathrm{~h}$, and then stimulated with TGF- $\beta$ for another hour before collection to test the phosphorylation level of Smads. TGF- $\beta 1$ dramatically induced $S m a d 2 / 3$ and Smad1/5/8 phosphorylation, and the addition of SB431542 [23] or LY364947 [25] completely inhibited this induction (fig. 3a), suggesting that ALK4/5/7 activity is required for TGF- $\beta$-mediated phosphorylation events. Most significantly, DM did not repress TGF- $\beta$-mediated induction of $S m a d 2 / 3$ or Smad1/5/8 phosphorylation (fig. 3a). As a control, DM was shown to repress BMP9- and BMP4-mediated Smad1/5/8 phosphorylation (fig. $3 b$ ). These data suggest that BMP type I receptors are not required for TGF- $\beta 1$ phosphorylation of Smad1/5/8 in SMC. 


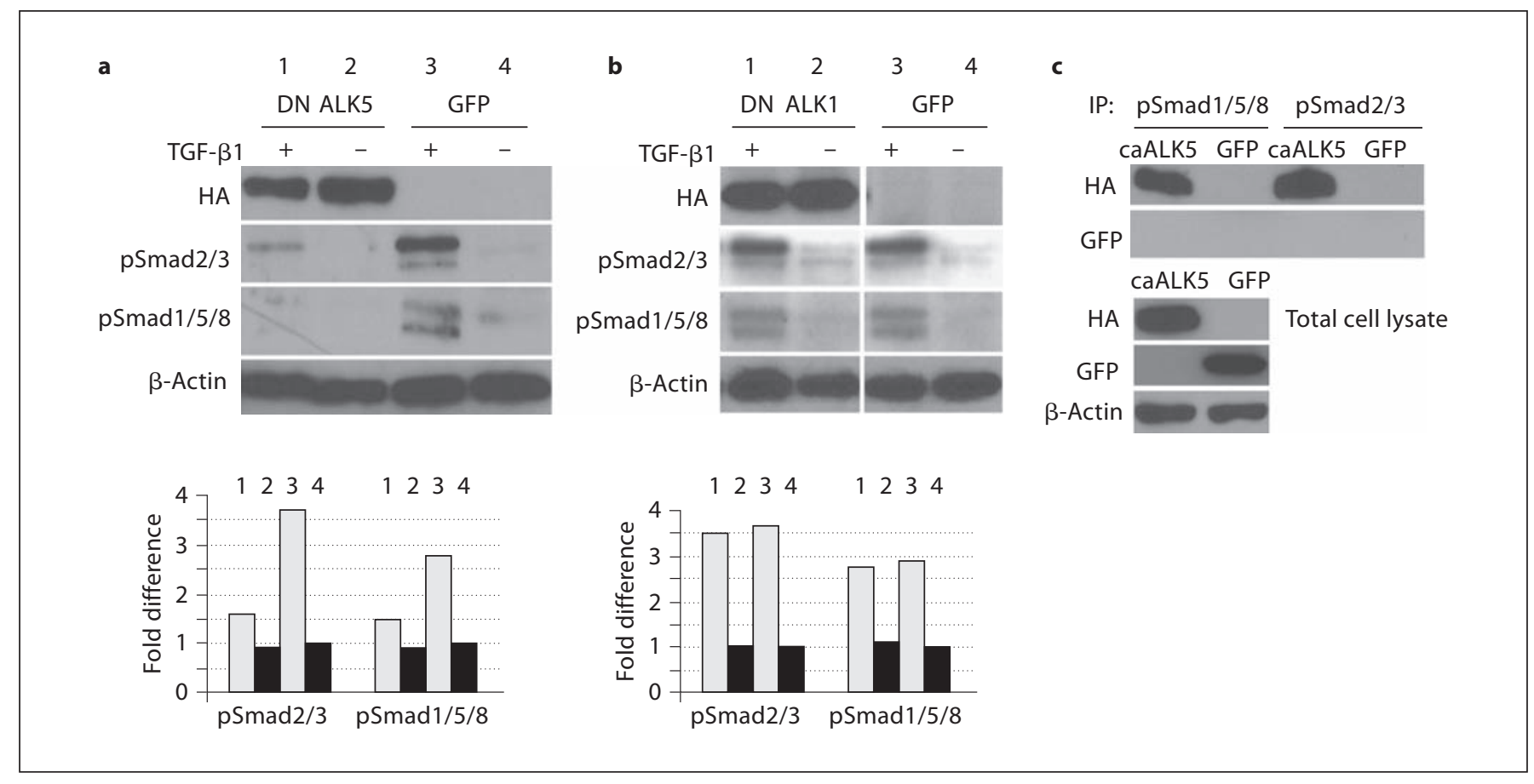

Fig. 4. ALK5, not ALK1, is required for TGF- $\beta 1$-induced Smad1/5/8 phosphorylation. a SMC were transduced with dominant negative ALK5 (DN ALK5) or GFP, serum starved for $24 \mathrm{~h}$, and then used as control (-) or treated with $2 \mathrm{ng} / \mathrm{ml} \mathrm{TGF}-\beta 1$ for $1 \mathrm{~h}(+)$. Cell lysates were collected to examine $\mathrm{pSmad} 2 / 3$ and pSmad1/5/8. Quantification of the immunoblot is shown underneath, corresponding to lanes 1-4 of the immunoblot. b SMC were transduced with dominant negative ALK1 (DN ALK1) or GFP, serum starved for $24 \mathrm{~h}$, and then used as control (-) or treated with $2 \mathrm{ng} / \mathrm{ml}$ TGF- $\beta 1$ for $1 \mathrm{~h}(+)$. Cell lysates were collected to examine pSmad2/3 and pSmad1/5/8. Quantification of the immunoblot is shown underneath, corresponding to lanes $1-4$ of the immunoblot. c SMC were transduced with constitutive active ALK5 (caALK5) or GFP for 3 days, and then collected for co-IP using $\mathrm{pSmad} 2 / 3$ or $\mathrm{pSmad} 1 / 5 / 8$ antibodies. The immunoprecipitated samples were used for immunoblot to detect CA ALK5 using anti-HA antibody. Specificity of the immunoprecipitation was tested by immunoblotting with anti-GFP. Ten percent of total cell lysates were run to detect caALK5 (anti-HA), GFP (anti-GFP) and $\beta$-actin by immunoblot analysis.

\section{ALK5 Is Required for TGF- $\beta$-Induced}

Phosphorylation of Smad1/5/8 in HASMC

Previous studies have shown that both ALK1 and ALK5 are required for TGF- $\beta 1$ signaling in endothelial cells and chondrocytes for Smad1/5/8 phosphorylation. Most recently, it was found that ALK1 is not always required for TGF- $\beta$-induced Smad1/5/8 phosphorylation. Our data show that ALK4/5/7 is required for TGF- $\beta$ phosphorylation of Smad1/5/8 in SMC (fig. 3a). As ALK5 is thought to be specific for the phosphorylation of Smad $2 / 3$ by TGF- $\beta$, we investigated whether ALK5 is could also initiate the phosphorylation of Smad1/5/8 in HASMC. The kinetics of TGF- $\beta$-induced Smad phosphorylation supports this possibility (fig. 2a). HASMC were transduced with dnALK5 before TGF- $\beta 1$ addition. The overexpression of dnALK5 inhibited TGF- $\beta$-induced $S m a d 2 / 3$ and Smad1/5/8 phosphorylation (fig. $4 a$ ), showing that ALK5 kinase activity is required for TGF- $\beta$ phosphorylation of Smad1/5/8 in HASMC. To further assess the role of ALK1 in Smad1/5/8 phosphorylation, HASMC were transduced with dominant negative ALK1 (DN1), and then stimulated with TGF- $\beta 1$. DN1 did not repress TGF- $\beta$-induced Smad phosphorylation (fig. $4 \mathrm{~b}$ ), suggesting an ALK1-independent pathway. The caALK5 can mimic TGF- $\beta$ action to phosphorylate Smad $2 / 3$ and Smad1/5/8 [19]. These phosphorylation events should be a direct reflection of caALK 5 activity because no TGF- $\beta$ or BMP was added to stimulate the activity of additional receptors. ALK5-induced Smad2/3 phosphorylation is through the direct interaction of ALK5 and Smad2/3. If ALK5 can directly phosphorylate $S m a d 1 / 5 / 8$, we predicted that these proteins would interact. To test this hypothesis, HASMC were transduced with caALK5, and lysates subjected to immunoprecipitation using anti-pSmad1/5/8 


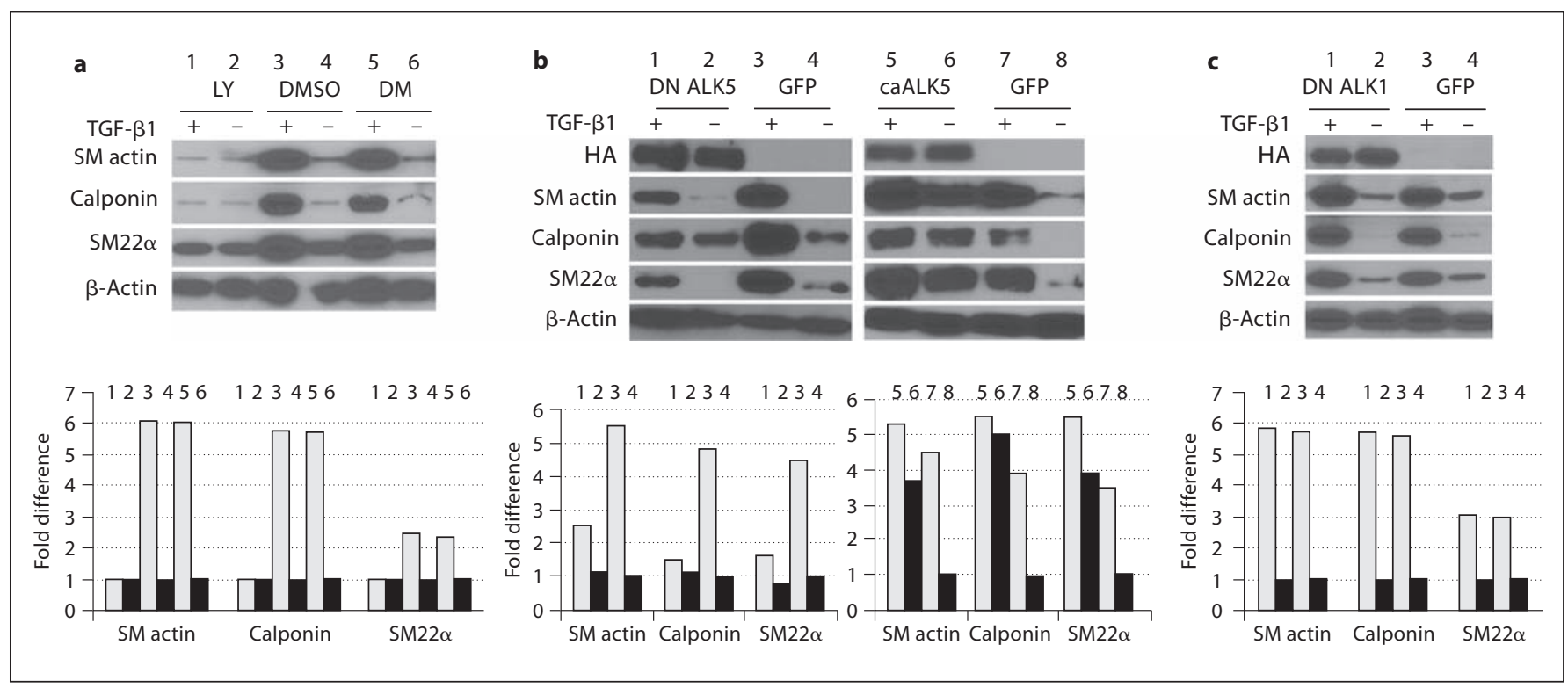

Fig. 5. ALK5, but not ALK1, is required for TGF- $\beta 1$-mediated SMC differentiation. a Primary HASMC were serum starved for $24 \mathrm{~h}$, then used as control (-) or treated with $2 \mathrm{ng} / \mathrm{ml} \mathrm{TGF}-\beta 1$ for $48 \mathrm{~h}(+)$ in the presence of $10 \mu \mathrm{M}$ SB431542, DMSO, or $10 \mu \mathrm{M} \mathrm{DM}$. Cell lysates were collected for immunoblot analysis for proteins indicated. Quantification of the immunoblot is shown underneath, corresponding to lanes $1-6$ of the immunoblot and the indicated proteins. b GFP, DN ALK5 or caALK5-transduced SMC were serum starved for $24 \mathrm{~h}$, then used as control (-) or treated with $2 \mathrm{ng} / \mathrm{ml}$ TGF- $\beta 1$ for $48 \mathrm{~h}(+)$. Cell lysates were collected for immunoblot analysis. Quantification of the immunoblot is shown underneath, corresponding to lanes $1-4$ or 5-8 with the indicated proteins. c GFP or DN ALK1 transduced SMC were serum starved for $24 \mathrm{~h}$, then used as control (-) or treated with $2 \mathrm{ng} / \mathrm{ml} \mathrm{TGF-} \beta 1$ for $48 \mathrm{~h} \mathrm{(+).} \mathrm{Cell} \mathrm{lysates} \mathrm{were} \mathrm{collected} \mathrm{for} \mathrm{immunoblot} \mathrm{analysis.}$ Quantification of the immunoblot is shown underneath, corresponding to lanes 1-4 of the immunoblot. or anti-pSmad2/3 antibodies. We observed that both $\mathrm{pSmad} 1 / 5 / 8$ and $\mathrm{pSmad} 2 / 3$ are able to co-immunoprecipitate with caALK5 (fig. 4c), suggesting that these proteins indeed interact. Specificity of this interaction was shown by transfection of cells with control GFP and immunoblot with anti-GFP. Both caALK5 and GFP were found in total cell lysates. These data combined with the kinetics of TGF- $\beta$-induced $\mathrm{pSmads}$ provide further evidence that Smad1/5/8 might also be a target of ALK5 phosphorylation in HASMC.

\section{ALK5, Not BMP Type I Receptor, Is Required for}

TGF- $\beta$-Induced SMC-Specific Gene Expression

Although TGF- $\beta$ can induce SMC-specific gene expression, little is known about whether TGF- $\beta$ requires BMP type I receptor signaling to accomplish this. To address this question, the specific inhibitors SB431542 and DM were added to TGF- $\beta 1$-treated cells. Stimulation by TGF- $\beta$ dramatically regulated SM marker expression (fig. 5a), which was inhibited by the ALK4/5/7 blocker, SB431542 (fig. 5a). However, DM did not have a significant effect on TGF- $\beta$-induced SMC differentiation markers (fig. $5 \mathrm{a}$ ), suggesting that the TGF- $\beta$ receptors, not the BMP type I receptors, are required. To further study the role of the specific TGF- $\beta$ type I receptor in HASMC differentiation, cells were transduced with dnALK1 and dnALK5, and then treated with TGF- $\beta 1$. Expression of dnALK5 suppressed TGF- $\beta$-mediated induction of SM actin and calponin 1 expression (fig. 5b). To further test the role of ALK5 signaling, HASMC were transduced with caALK5. We found that caALK5 mimics TGF- $\beta$ action in inducing SM-specific gene expression (fig. 5b). Unlike inhibition of ALK5 signaling, expression of dnALK1 did not repress TGF- $\beta$-regulated SMC differentiation (fig. $5 \mathrm{c}$ ). These data show that the active receptor propagating TGF- $\beta$ signals leading to HASMC differentiation is ALK5.

\section{Endoglin Does Not Oppose TGF- $\beta$ Action in \\ Promoting SM Gene Expression}

Endoglin, a type III receptor, can inhibit TGF- $\beta$ action in endothelial cells through ALK5/Smad2/3 [26]. Endoglin is a target gene of TGF- $\beta$ signaling pathway in SMC 
Fig. 6. The expression of endoglin does not oppose TGF- $\beta 1$-mediated SMC differentiation. GFP or endoglin transduced SMC were serum starved for $24 \mathrm{~h}$, then used as control (-) or treated with $2 \mathrm{ng} / \mathrm{ml} \mathrm{TGF}-\beta 1$ for $48 \mathrm{~h} \mathrm{(+).} \mathrm{Cell} \mathrm{lysates} \mathrm{were} \mathrm{collected} \mathrm{for}$ immunoblot analysis to detect endoglin, SM actin, calponin $1, S M 22 \alpha$ and $\beta$-actin. Quantification of SMC marker levels is shown on the right, corresponding to lanes $1-4$ of the immunoblot.

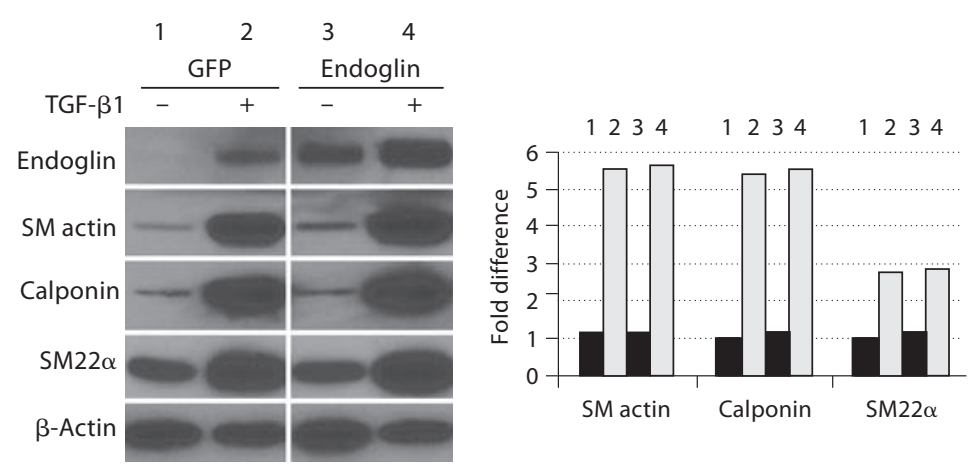

implicated in TGF- $\beta 1$ signaling $[5,7-9,27]$. Following TGF- $\beta 1$ treatment, we found significant activation of ERK1/2, and some activation of JNK and p38 (fig. 7c). We therefore utilized inhibitors of PI3K/Akt and MAP kinase signaling, including U0126 (MEK/Erk) [28], LY294002 (PI3K/Akt) [29], SP600125 (JNK) [30] and SB201090 (p38) [31]. We found that MAP kinase signaling is required for TGF- $\beta$-induced SMC differentiation, but PI3K/Akt signaling is not (fig. 7d, e). In addition, when MAPK inhibitors were used in combination with suppression of Smad3 (SIS3), we found enhanced suppression of smooth marker expression (fig. 7f). Therefore, TGF- $\beta 1$ activates both Smad3-dependent and Smad-independent signals that contribute to the TGF- $\beta$-induced SMC differentiation phenotype.

\section{Discussion}

TGF- $\beta$ plays an important role in vascular development and vascular disorders. However, the precise mechanisms by which it exerts its effects are not entirely clear, especially in SMC phenotype transition. One unique feature representing the multifunctional nature of TGF- $\beta$ is the diverse repertoire of signaling, which was recently reported in endothelial cells, neurons and chondrocytes $[18,32,33]$. The present study characterizes TGF- $\beta 1$ downstream pathways regulating SMC marker expression in HASMC. We demonstrate that TGF- $\beta 1$ phosphorylates Smad1/5/8 and Smad2/3 in HASMC, and that BMP type I receptors are not required for TGF- $\beta$-mediated phosphorylation of Smad1/5/8. Furthermore, we identify ALK5, but not ALK1, as the signaling receptor whose activation leads to phosphorylation of Smad1/5/8 and SMC marker expression. These pathways were not 


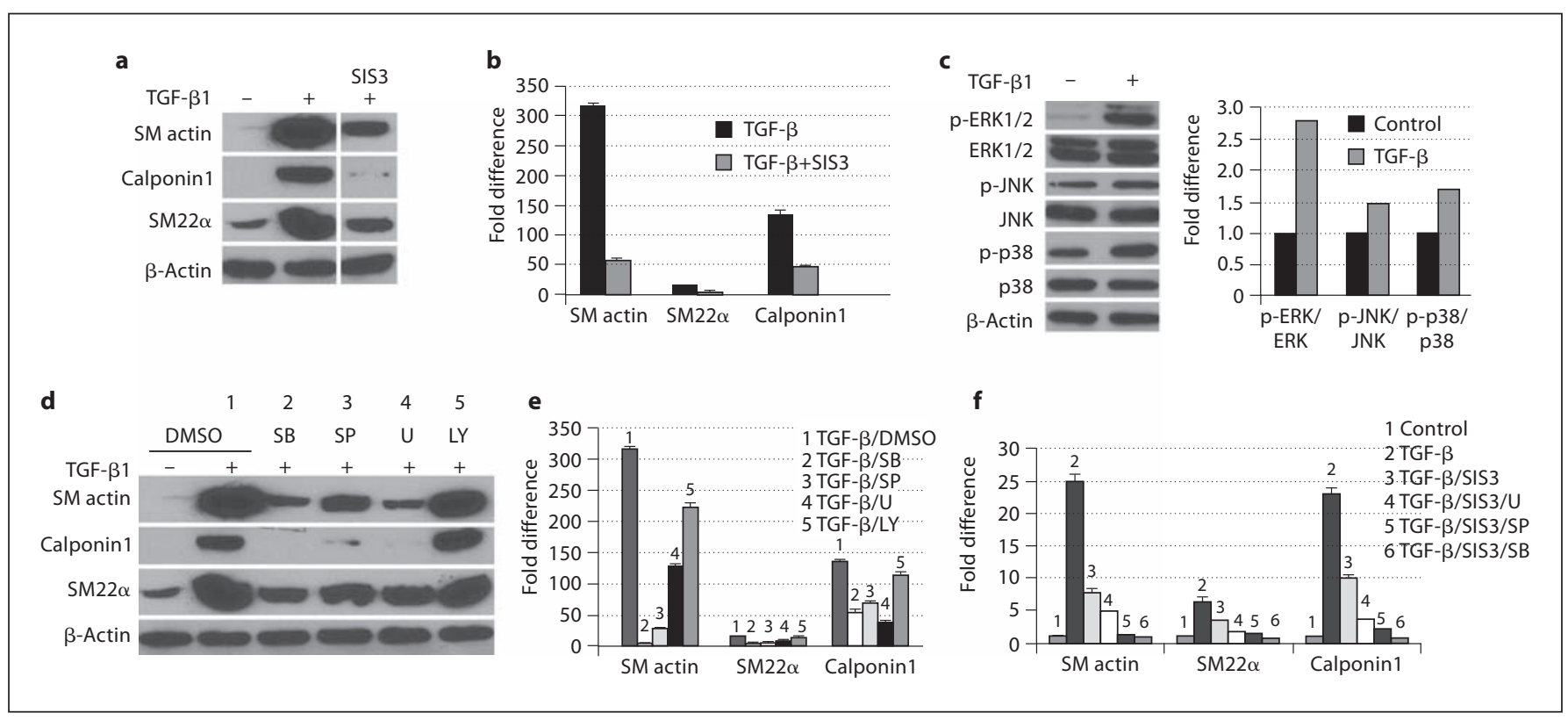

Fig. 7. ALK5/Smad 3 and MAPK signaling are required for TGF$\beta 1$-mediated SMC differentiation. a Serum-starved HASMC were used as control (-) or stimulated with $2 \mathrm{ng} / \mathrm{ml}$ TGF- $\beta 1$ for $48 \mathrm{~h} \mathrm{(+)}$ in the presence or absence of a Smad3-specific inhibitor (SIS3) at $10 \mu \mathrm{M}$. Cell lysates were collected for immunoblot. b SMC were serum starved for $24 \mathrm{~h}$, and then treated with $2 \mathrm{ng} / \mathrm{ml} \mathrm{TGF}-\beta 1$ for $24 \mathrm{~h}$ in the presence or absence of Smad3-specific inhibitor (SIS3). Cells were collected for quantitative RT-PCR. c SMC were used as control (-) or treated with $2 \mathrm{ng} / \mathrm{ml} \mathrm{TGF}-\beta 1$ for $1 \mathrm{~h}(+)$ and lysates collected for immunoblot. Active forms of ERK1/2, JNK and p38 were quantified by ratio of phosphophorylated versus total proteins (right). d Serum-starved SMC were used as control (-) or stimulated with $2 \mathrm{ng} / \mathrm{ml} \mathrm{TGF}-\beta 1$ for $48 \mathrm{~h}(+)$ in the presence of 10 $\mu$ M LY294002 (LY), $10 \mu$ M U0126 (U), $10 \mu \mathrm{M}$ SP600125 (SP), 10 $\mu \mathrm{M}$ SB202190 (SB) or DMSO. Cell lysates were collected after treatment for immunoblot. e SMC were serum starved for $24 \mathrm{~h}$, and then treated with $2 \mathrm{ng} / \mathrm{ml} \mathrm{TGF-} \beta 1$ for $24 \mathrm{~h}$ in the presence of control DMSO, SB202190 (SB), SP600125 (SP), U0126 (U) or LY294002 (LY). Cells were collected for quantitative RT-PCR. Data are presented as fold change compared to control SMC without TGF- $\beta 1$ stimulation \pm standard deviation. $\mathbf{f}$ Cells were treated as in e, except inhibitors were used in combination with the Smad inhibitor SIS3. Expression of SMC markers indicated was analyzed by quantitative RT-PCR. influenced by increased endoglin, a TGF- $\beta$ type III receptor that modifies TGF- $\beta$ responses in some cellular contexts. Both ALK5/Smad3-mediated and Smad-independent pathways are activated by TGF- $\beta$ in HASMC. Taken together, our findings show that TGF- $\beta$ responses in SMC are regulated in a multipathway manner, and emphasize that these molecular pathways are cell type specific.

In endothelial cells, various studies show that TGF- $\beta$ phosphorylates SMAD2/3 and SMAD1/5/8 through TGF- $\beta$ type 1 receptors ALK5 and ALK1, respectively, and that ALK1 opposes ALK5/SMAD2/3 signaling [18, 21]. Moreover, the type III receptor endoglin inhibits TGF- $\beta$ /ALK5 signaling function by enhancing ALK1 signals in endothelial cells [26]. The vascular importance of ALK1 and endoglin was further supported by their null mutant phenotypes, which are characterized by vascular and cardiac abnormalities with embryonic lethal- ity by E10-10.5 [34-36]. Distinct TGF- $\beta$ signals propagated through ALK1 versus ALK5 also occur in neurons and human chondrocytes $[32,33]$. In HaCaT keratinocytes, TGF- $\beta$-induced Smad1 phosphorylation requires the BMP type I receptor ALK2, since no ALK1 expression was observed in these cells [22]. Smad1 phosphorylation by TGF- $\beta$ stimulation was detected in several epithelial cells and fibroblasts via ALK5 and ALK2 and/or ALK3 [37]. These studies and a recent report by Wrighton et al. [19] suggest that activation of Smad1 by TGF- $\beta$ is a common phenomenon. However, the mechanisms of TGF- $\beta$-mediated Smad1 phosphorylation are cell type dependent. In some cells such as C2C12, TGF- $\beta$ phosphorylates Smad1 independently of BMP receptors [19], while other cells require various BMP receptors for the phosphorylation of Smad1 $[18,32,33]$. However, little is understood about specific TGF- $\beta$ pathways relevant in SMC. 
One major function of TGF- $\beta 1$ is to regulate SMC differentiation, which it does by targeting SMC markers such as SM actin, SM22 $\alpha$, and calponin 1 in different cell types such as $10 \mathrm{~T} 1 / 2$ cells, SMC, neural crest cells, bone marrow stromal cells and fibroblasts [3-5, 27]. However, the downstream signaling in these various cell sources is diverse. In bone marrow stromal cells, ALK5/Smad3, Rho kinase activity and Notch signaling are involved in TGF- $\beta 1$-mediated SMC differentiation [27]. In neural crest stem cell line Monc-1, RhoA modulates TGF- $\beta 1$-involved SMC differentiation [7]. In 10T1/2 cells, Erk1/2 activity and PI3k/Akt are involved in TGF- $\beta 1$-regulated differentiation $[5,9]$. In the PAC-1 SMC line, TGF- $\beta 1$ induced expression of SM marker genes involves activation of PKN and p38 MAPK [8].

In addition to Smad3-dependent role of TGF- $\beta$ in SMC differentiation, we also found that MAP kinase signaling is required for TGF- $\beta$-mediated SMC marker induction. Endoglin, a TGF- $\beta$ type III receptor that is highly expressed in injurious artery and atherosclerotic plaques $[11,12]$, is one TGF- $\beta$ target gene in HASMC, which was reported to repress TGF- $\beta / \operatorname{Smad} 2 / 3$ signaling in endothelial cells at high expression levels. In HASMC, we did not observe this activity by endoglin, showing that endoglin activity is different in vascular cells. Although we did not detect a role for PI3k/Akt in regulation of SMC markers, we cannot rule out the possibility that PI3K/Akt or endoglin may be functionally significant in other TGF- $\beta$ phenotypes such as cell migration, cell cycle pro- gression or regulation of other genes. Src-dependent TGF- $\beta$ type II receptor phosphorylation leads to the recruitment of GRB2 and SHC as well as the activation of the p38 MAPK pathway, which plays a pivotal role in breast cancer cell proliferation and invasiveness $[38,39]$. TGF- $\beta$-induced receptor heterotetramers recruiting the ubiquitin ligase tumor necrosis factor- $\alpha$ receptor-associated factor 6 (TRAF6) to the cytoplasmic domain of TGF$\beta$ type I receptor in mammalian cells lead to the activation of p38 and c-JNK cascades, which regulate apoptosis or cell migration $[40,41]$. Therefore, future experiments to investigate the role of various TGF- $\beta$ pathways in SMC proliferation and migration are warranted. In conclusion, TGF- $\beta$ activates diverse signaling pathways to regulate SMC differentiation markers in a cell type-specific manner. These observations have implications to cardiovascular disease and developmental pathways known to involve TGF- $\beta$ superfamily signaling.

\section{Acknowledgements}

This work was supported by National Institutes of Health grants R01HL070865 (L.L.), P20RR15555 from the National Center for Research Resources (R.E.F. and L.L.), and R01HL65301 (R.E.F.). Y.T. was supported by a predoctoral fellowship from the Founders Affiliate of the American Heart Association. Y.T. completed this work in partial fulfillment of requirements for a doctorate of philosophy at the University of Maine, Orono.

\section{References}

1 Bobik A: Transforming growth factor- $\beta$ and vascular disorders. Arterioscler Thromb Vasc Biol 2006;26:1712-1720.

2 Massague J: TGF $\beta$ in cancer. Cell 2008;134: 215-230.

-3 Chambers RC, Leoni P, Kaminski N, Laurent GJ, Heller RA: Global expression profiling of fibroblast responses to transforming growth factor- $\beta 1$ reveals the induction of inhibitor of differentiation- 1 and provides evidence of smooth muscle cell phenotypic switching. Am J Pathol 2003;162:533-546.

$\checkmark 4$ Chen S, Lechleider RJ: Transforming growth factor- $\beta$-induced differentiation of smooth muscle from a neural crest stem cell line. Circ Res 2004;94:1195-1202.

5 Lien SC, Usami S, Chien S, Chiu JJ: Phosphatidylinositol 3-kinase/akt pathway is involved in transforming growth factor- $\beta 1$-induced phenotypic modulation of $10 \mathrm{t} 1 / 2$ cells to smooth muscle cells. Cell Signal 2006;18: $1270-1278$

TGF- $\beta /$ Smad Signaling in Human Smooth Muscle Cells
6 Kalinina N, Agrotis A, Antropova Y, Ilyinskaya O, Smirnov V, Tararak E, Bobik A: Smad expression in human atherosclerotic lesions: Evidence for impaired TGF- $\beta /$ smad signaling in smooth muscle cells of fibrofatty lesions. Arterioscler Thromb Vasc Biol 2004; 24:1391-1396.

7 Chen S, Crawford M, Day RM, Briones VR, Leader JE, Jose PA, Lechleider RJ: Rhoa modulates Smad signaling during transforming growth factor- $\beta$-induced smooth muscle differentiation. J Biol Chem 2006;281:17651770 .

$\checkmark 8$ Deaton RA, Su C, Valencia TG, Grant SR: Transforming growth factor- $\beta 1$-induced expression of smooth muscle marker genes involves activation of pkn and p38 MAPK. J Biol Chem 2005;280:31172-31181.
-9 Kawai-Kowase K, Sato H, Oyama Y, Kanai H, Sato M, Doi H, Kurabayashi M: Basic fibroblast growth factor antagonizes transforming growth factor- $\beta 1$-induced smooth muscle gene expression through extracellular signal-regulated kinase 1/2 signaling pathway activation. Arterioscler Thromb Vasc Biol 2004;24:1384-1390.

10 Tang Y, Urs S, Boucher J, Bernaiche T, Venkatesh D, Spicer DB, Vary CP, Liaw L: Notch and TGF $\beta$ signaling pathways cooperatively regulate vascular smooth muscle cell differentiation. J Biol Chem 2010;285:1755614563.

- 11 Conley BA, Smith JD, Guerrero-Esteo M, Bernabeu C, Vary CP: Endoglin, a tgf- $\beta$ receptor-associated protein, is expressed by smooth muscle cells in human atherosclerotic plaques. Atherosclerosis 2000; 153:323335 . 
-12 Ma X, Labinaz M, Goldstein J, Miller H, Keon WJ, Letarte M, O’Brien E: Endoglin is overexpressed after arterial injury and is required for transforming growth factor- $\beta$-induced inhibition of smooth muscle cell migration. Arterioscler Thromb Vasc Biol 2000;20:2546-2552.

-13 Aoki K, Barker C, Danthinne X, Imperiale MJ, Nabel GJ: Efficient generation of recombinant adenoviral vectors by cre-lox recombination in vitro. Mol Med 1999;5:224-231.

$\checkmark 14$ Koleva RI, Conley BA, Romero D, Riley KS, Marto JA, Lux A, Vary CP: Endoglin structure and function: Determinants of endoglin phosphorylation by transforming growth factor- $\beta$ receptors. J Biol Chem 2006;281: $25110-25123$

15 Tang Y, Urs S, Liaw L: Hairy-related transcription factors inhibit notch-induced smooth muscle $\alpha$-actin expression by interfering with notch intracellular domain/CBF1 complex interaction with the CBF-1-binding site. Circ Res 2008;102:661-668.

-16 Havrda MC, Johnson MJ, O’Neill CF, Liaw L: A novel mechanism of transcriptional repression of p27kip1 through notch/hrt2 signaling in vascular smooth muscle cells. Thromb Haemost 2006;96:361-370.

$\checkmark 17$ King IN, Kathiriya IS, Murakami M, Nakagawa M, Gardner KA, Srivastava D, Nakagawa O: Hrt and Hes negatively regulate notch signaling through interactions with RBP-Јк. Biochem Biophys Res Commun 2006;345: 446-452.

18 Goumans MJ, Valdimarsdottir G, Itoh S, Rosendahl A, Sideras P, ten Dijke P: Balancing the activation state of the endothelium via two distinct TGF- $\beta$ type I receptors. EMBO J 2002;21:1743-1753.

$\checkmark 19$ Wrighton KH, Lin X, Yu PB, Feng XH: Transforming growth factor $\beta$ can stimulate smad1 phosphorylation independently of bone morphogenic protein receptors. J Biol Chem 2009;284:9755-9763.

20 Korchynskyi O, ten Dijke P: Identification and functional characterization of distinct critically important bone morphogenetic protein-specific response elements in the id1 promoter. J Biol Chem 2002;277:4883-4891.

-21 Goumans MJ, Valdimarsdottir G, Itoh S, Lebrin F, Larsson J, Mummery C, Karlsson $S$, ten Dijke P: Activin receptor-like kinase (Alk)1 is an antagonistic mediator of lateral TGFß/Alk5 signaling. Mol Cell 2003;12:817828 .
22 Bharathy S, Xie W, Yingling JM, Reiss M: Cancer-associated transforming growth factor $\beta$ type II receptor gene mutant causes activation of bone morphogenic protein-smads and invasive phenotype. Cancer Res 2008; 68:1656-1666.

23 Inman GJ, Nicolas FJ, Callahan JF, Harling JD, Gaster LM, Reith AD, Laping NJ, Hill CS $\mathrm{Sb}-431542$ is a potent and specific inhibitor of transforming growth factor- $\beta$ superfamily type I activin receptor-like kinase (Alk) receptors Alk4, Alk5, and Alk7. Mol Pharmacol 2002;62:65-74.

24 Yu PB, Hong CC, Sachidanandan C, Babitt JL, Deng DY, Hoyng SA, Lin HY, Bloch KD, Peterson RT: Dorsomorphin inhibits BMP signals required for embryogenesis and iron metabolism. Nat Chem Biol 2008;4:33-41.

25 Sawyer JS, Anderson BD, Beight DW, Campbell RM, Jones ML, Herron DK, Lampe JW, McCowan JR, McMillen WT, Mort N, Parsons S, Smith EC, Vieth M, Weir LC, Yan L, Zhang F, Yingling JM: Synthesis and activity of new aryl- and heteroaryl-substituted pyrazole inhibitors of the transforming growth factor- $\beta$ type I receptor kinase domain. Med Chem 2003;46:3953-3956

-26 Lebrin F, Goumans MJ, Jonker L, Carvalho RL, Valdimarsdottir G, Thorikay M, Mummery C, Arthur HM, ten Dijke P: Endoglin promotes endothelial cell proliferation and tgf- $\beta$ /alk1 signal transduction. EMBO J 2004;23:4018-4028.

27 Kurpinski K, Lam H, Chu J, Wang A, Kim A, Tsay E, Agrawal S, Schaffer D, Li S: Tgf- $\beta$ and notch signaling mediate stem cell differentiation into smooth muscle cells. Stem Cells 2010;28:734-742.

28 Favata MF, Horiuchi KY, Manos EJ, Daulerio AJ, Stradley DA, Feeser WS, Van Dyk DE, Pitts WJ, Earl RA, Hobbs F, Copeland RA, Magolda RL, Scherle PA, Trzaskos JM: Identification of a novel inhibitor of mitogen-activated protein kinase kinase. J Biol Chem 1998;273:18623-18632.

29 Vlahos CJ, Matter WF, Hui KY, Brown RF: A specific inhibitor of phosphatidylinosito 3-kinase, 2-(4-morpholinyl)-8-phenyl-4h-1benzopyran-4-one (ly294002). J Biol Chem 1994;269:5241-5248.

30 Bennett BL, Sasaki DT, Murray BW, O’Leary EC, Sakata ST, Xu W, Leisten JC, Motiwala A, Pierce S, Satoh Y, Bhagwat SS, Manning AM, Anderson DW: Sp600125, an anthrapyrazolone inhibitor of Jun N-terminal kinase. Proc Natl Acad Sci USA 2001;98: 13681-13686.
31 Warrior U, Chiou XG, Sheets MP, Sciotti RJ, Parry JM, Simmer RL, Surber BW, Burns DJ, Beutel BA, Mollison KW, Djuric SW, Trevillyan JM: Development of a p38 kinase binding assay for high throughput screening. J Biomol Screen 1999;4:129-135.

>32 Konig HG, Kogel D, Rami A, Prehn JH: TGF$\beta 1$ activates two distinct type i receptors in neurons: Implications for neuronal NF- $\mathrm{B}$ signaling. J Cell Biol 2005;168:1077-1086.

-33 Finnson KW, Parker WL, ten Dijke P, Thorikay M, Philip A: Alk1 opposes Alk5/Smad3 signaling and expression of extracellular matrix components in human chondrocytes. J Bone Miner Res 2008;23:896-906.

34 Oh SP, Seki T, Goss KA, Imamura T, Yi Y, Donahoe PK, Li L, Miyazono K, ten Dijke P, Kim S, Li E: Activin receptor-like kinase 1 modulates transforming growth factor- $\beta 1$ signaling in the regulation of angiogenesis. Proc Natl Acad Sci USA 2000;97:2626-2631.

35 Urness LD, Sorensen LK, Li DY: Arteriovenous malformations in mice lacking activin receptor-like kinase-1. Nat Genet 2000;26: 328-331.

36 Li DY, Sorensen LK, Brooke BS, Urness LD, Davis EC, Taylor DG, Boak BB, Wendel DP: Defective angiogenesis in mice lacking endoglin. Science 1999;284:1534-1537.

37 Daly AC, Randall RA, Hill CS: Transforming growth factor $\beta$-induced smad $1 / 5$ phosphorylation in epithelial cells is mediated by novel receptor complexes and is essential for anchorage-independent growth. Mol Cell Biol 2008;28:6889-6902.

-38 Galliher AJ, Schiemann WP: Src phosphorylates Tyr284 in TGF- $\beta$ type II receptor and regulates TGF- $\beta$ stimulation of p38 Mapk during breast cancer cell proliferation and invasion. Cancer Res 2007;67:3752-3758.

39 Galliher-Beckley AJ, Schiemann WP: Grb2 binding to Tyr284 in TßR-II is essential for mammary tumor growth and metastasis stimulated by TGF- $\beta$. Carcinogenesis 2008 ; 29:244-251.

40 Sorrentino A, Thakur N, Grimsby S, Marcusson A, von Bulow V, Schuster N, Zhang S, Heldin $\mathrm{CH}$, Landstrom M: The type I TGF- $\beta$ receptor engages Traf6 to activate Tak1 in a receptor kinase-independent manner. Nat Cell Biol 2008;10:1199-1207.

-41 Yamashita M, Fatyol K, Jin C, Wang X, Liu Z, Zhang YE: Traf6 mediates Smad-independent activation of JNK and p38 by TGF- $\beta$. Mol Cell 2008;31:918-924. 